\title{
Variabel-Variabel Relasional Kesiapan Belajar Peserta Didik di Tingkat Sekolah Dasar
}

\section{Jumasrin}

Dinas Pendidikan dan Kebudayaan Kolaka Timur email: jumasrin.koltim@gmail.com

\begin{abstract}
Abstrak
Pendidikan tingkat dasar memerlukan penanganan serius dalam penanaman dasar-dasar pendidikan. Peserta didik pada jenjang ini memerlukan kesiapan mental dan fisik agar dapat menyesuaikan diri dalam proses pembelajaran. Sebagai peserta didik yang sepenuhnya dibimbing oleh orang dewasa, diperlukan desain terciptanya kondisi yang dapat menumbuhkan kesiapan mereka dalam belajar. Variabel perhatian orang tua dan motivasi belajar merupakan variabel yang terhubung kuat dengan kesiapan belajar siswa pada tingkat sekolah dasar. Keluarga merupakan sekolah pertama bagi anak, sehingga kondisi rumah dan terutama orang tua mesti mendukung proses seorang anak dalam meningkatkan kualitas belajar. Perhatian orang tua harus terwujud dalam sebuah ikhtiar sistematis untuk menyiapkan sang anak memasuki dunia sekolah. Perhatian orang tua tidak diwujudkan dalam aspek-aspek yang bernilai hedonispermisif. Keluarga harus dapat menunjukkan energi motivatif bagi kesiapan belajar. Memasuki lingkungan sekolah, iklim belajar mesti dapat diciptakan sehingga peserta didik merasakan pengalaman belajar yang nyaman dan menyenangkan. Keberadaan guru juga harus menjadi penggerak siswa untuk mencintai pembelajaran. Suntikan motivasi secara terus-menerus harus dapat dilakukan oleh para guru, dalam berbagai bentuk, dengan cara-cara yang inovatif. Kolaborasi antara lingkungan keluarga dalam bentuk perhatian orang tua dan lingkungan sekolah dalam bentuk penumbuhan motivasi belajar diyakini memiliki pengaruh kuat pada kesiapan belajar siswa pada tingkat sekolah dasar.
\end{abstract}

\section{Kata Kunci: Kesiapan Belajar, Motivasi, Perhatian Orang Tua}




\title{
Relational Variables of Student Learning Readiness at the Elementary School Level
}

\section{Jumasrin}

Dinas Pendidikan dan Kebudayaan Kolaka Timur email: jumasrin.koltim@gmail.com

\begin{abstract}
Basic level education requires serious handling in planting the basics of education. Students at this level require mental and physical readiness to be able to adjust to the learning process. As students who are fully guided by adults, it is necessary to design the creation of conditions that can foster their readiness in learning. Variables of parental attention and learning motivation are strongly connected variables with student learning readiness at the elementary school level. Family is the first school for children, so the condition of the house and especially parents must support a child's process in improving the quality of learning. Parental attention must be realized in a systematic effort to prepare the child to enter the school world. Parents' attention is not manifested in hedonic-permissive aspects. Families must be able to show motivational energy for learning readiness. Entering the school environment, the learning climate must be created so that students feel a comfortable and pleasant learning experience. The existence of a teacher must also be a driver of students to love learning. Continuous motivation injections must be carried out by the teachers, in various forms, in innovative ways. Collaboration between the family environment in the form of parental attention and the school environment in the form of developing learning motivation is believed to have a strong influence on student learning readiness at the elementary school level.
\end{abstract}

Keywords: Learning Readiness, Motivation, Attention of Parents 


\section{Pendahuluan}

Pendidikan adalah salah satu modal utama dalam menghadapi tantangan di era globalisasi ini. Pendidikan merupakan proses pendewasaan secara sadar dan terencana untuk mengoptimalkan potensi peserta didik, sehingga terbentuk watak, karakter, dan kepribadian sebagai manusia seutuhnya. Pendidikan yang baik diharapkan dapat meningkatkan dan mengembangkan seluruh potensi peserta didik sehingga menjadi manusia yang lebih baik.

Ki Hajar Dewantara menyatakan bahwa yang dinamakan Pendidikan adalah tuntunan dalam hidup tumbuhnya anak-anak. Setiap anak akan tumbuh dan berkembang menjadi dewasa, dalam proses inilah seorang anak memerlukan tuntunan atau pedoman agar dalam prosesnya dapat tumbuh dengan baik ${ }^{1}$. Tidak dapat dipungkiri bahwa ini merupakan tugas yang berat bagi para pendidik. Pendidik tidak hanya dituntut untuk dapat mengajarkan ilmu tetapi lebih mengutamakan pada mendidik dan menuntun anak agar menjadi manusia yang berkualitas. Sehingga pendidik memiliki tanggungjawab yang besar terhadap keberhasilan dalam proses belajar mengajar. Keseluruhan proses pembelajaran di sekolah merupakan kegiatan yang paling pokok dan utama. Dalam hal ini berarti berhasil atau tidaknya pembelajaran bergantung pada proses belajar yang dialami anak.

Proses belajar mengajar merupakan serangkaian aktivitas yang terdiri dari persiapan, pelaksaaan dan evaluasi pebelajaran. Ketiga hal tersebut merupakan rangkaian utuh yang tidak dapat dipisahkan. Persiapan belajar mengajar merupakan penyiapan segala sesuatu yang diperlukan dalam proses pembelajaran yang meliputi kompetensi inti dan kompentesi dasar, alat evaluasi, bahan ajar, metode pembelajaran, media/alat peraga pendidikan, fasilitas, waktu, tempat, dana, harapanharapan, kesiapan siswa dan perangkat informasi yang diperlukan untuk mendukung pelaksaan belajar mengajar.

Keberhasilan program pendidikan melalui proses belajar mengajar dipengaruhi oleh beberapa faktor yaitu ${ }^{2}$ : siswa, kurikulum, tenaga kependidikan, biaya, sarana dan prasarana serta faktor

1 Sugihartono, Psikologi Pendidikan (Yogyakarta: UNY Press 2007) h. 20

${ }^{2}$ Oemar Hamalik, Proses Belajar Mengajar (Jakarta: Bumi Aksara,2013), h. 45 
lingkungan. Apabila faktor-faktor tersebut dapat terpenuhi maka akan memperlancar proses belajar mengajar, yang akan menunjang pencapaian hasil belajar yang maksimal. Namun pada kenyataannya, tidak semua faktor terpenuhi. Sehingga mengakibatkan timbulnya permasalahan dalam pembelajaran.

Temuan-temuan sebelumnya menunjukkan siswa bermasalah dengan indikasi siswa kurang antusias dalam mengikuti pembelajaran di kelas, tidak mengerjakan pekerjaan rumah, dan membuat gaduh dengan berbuat nakal pada temannya. Setelah diselidiki lebih lanjut, ternyata siswa tersebut kurang memperoleh perhatian dari orang tua. Orang tua tidak memantau kegiatan belajar, acuh terhadap hasil belajar dan tidak memperhatikan kebutuhan fasilitas belajar anak. Sehingga kesiapan belajar siswa tersebut juga rendah, dengan indikasi siswa tidak membawa buku pelajaran, tidak mengerjakan PR, dan sering terlambat datang ke sekolah ${ }^{3}$. Ditemukan pula siswa yang antusias mengikuti pembelajaran, tidak membuat gaduh di kelas, dan memperoleh hasil belajar yang memuaskan. Setelah diselidiki lebih lanjut, ternyata siswa tersebut memperoleh perhatian dari orang tuanya. Orang tua selalu mengawasi kegiatan belajar, memantau hasil belajar dan menyediakan fasilitas belajar yang diperlukan anaknya. Sehingga siswa tersebut memiliki kesiapan belajar yang tinggi, dengan indikasi berangkat sekolah tepat waktu, selalu mengerjakan PR, membawa buku pelajaran, dan memiliki perlengkapan belajar ${ }^{4}$.

Kajian memandang bahwa kesiapan belajar berkaitan secara langsung dengan variabel-variabel di lingkungan keluarga dan sekolah.

\section{Motivasi Belajar}

"Motif" sebagai daya upaya yang mendorong seseorang untuk melakukan sesuatu. Berawal dari kata "motif" itu, maka motivasi dapat diartikan sebagai daya penggerak yang telah menjadi aktif. Motivasi dapat dikatakan sebagai dorongan mental yang

${ }^{3}$ Bangun, Darwin. "Hubungan persepsi siswa tentang perhatian orang tua, kelengkapan fasilitas belajar, dan penggunaan waktu belajar di rumah dengan prestasi belajar ekonomi." Jurnal ekonomi dan pendidikan 5, no. 1 (2008).

${ }^{4}$ Kurniawan, Didik, and Dhoriva Urwatul Wustqa. "Pengaruh perhatian orangtua, motivasi belajar, dan lingkungan sosial terhadap prestasi belajar matematika siswa SMP." Jurnal riset pendidikan matematika 1, no. 2 (2014): 176187. 
menggerakkan untuk melakukan aktifitas-aktifitas tertentu untuk mencapai suatu tujuan. ${ }^{5}$

Motivasi adalah daya penggerak/ pendorong untuk melakukan suatu pekerjaan. Motivasi dikatakan sebagai penggerak, sehingga seseorang mau dan ingin melakukan sesuatu, dan bila ia tidak suka maka ia akan berusaha meniadakan perasaan tidak suka itu.

Motivasi merupakan dorongan yang terdapat dalam diri seseorang untuk berusaha mengadakan perubahan tingkah laku yang lebih baik dalam memenuhi kebutuhannya.

Motivasi merupakan suatu pendorong yang mengubah energi dalam diri seseorang ke dalam bentuk aktivitas yang nyata untuk mencapai tujuan tertentu. ${ }^{6}$ Motivasi adalah keadaan yang terdapat dalam diri seseorang yang mendorongnya untuk melakukan aktivitas tertentu guna pencapaian suatu tujuan. Motivasi juga bisa berbentuk usaha-usaha yang dapat menyebabkan seseorang tergerak untuk melakukan sesuatu karena ingin mencapai tujuan yang dikehendakinya atau memperoleh kepuasan dengan perbuatannya. Motivasi belajar adalah kecenderungan siswa dalam melakukan kegiatan belajar yang didorong oleh hasrat untuk mencapai prestasi atau hasil belajar sebaik mungkin. ${ }^{8}$ Motivasi belajar merupakan faktor psikis yang bersifat non intelektual. Peranannya adalah dalam hal penumbuhan gairah, merasa senang dan semangat untuk belajar. Siswa yang memiliki semangat untuk belajar akan lebih mudah memahami materi pembelajaran, sehingga tujuan pembelajaran akan tercapai. ${ }^{9}$ Motivasi belajar merupakan dorongan/penggerak maupun penyeleksi perbuatan dalam belajar. Motivasi yang dimiliki seseorang dapat menentukan perbuatan yang harus dilakukan maupun yang harus ditinggalkan guna mencapai tujuan yang dikehendaki. Motivasi belajar sebagai kekuatan mental yang mendorong terjadinya belajar. Kekuatan mental tersebut berupa keinginan, perhatian, kemauan atau

${ }^{5}$ Sardiman, Interaksi \& Motivasi Belajar Mengajar (Jakarta: Rajawali Press 2017), h.73.

6 Syaiful Bahri Djamarah, Rahasia Sukses Belajar (Jakarta: Rineka Cipta,2008), h 148.

${ }^{7}$ Djaali, Psikologi Pendidikan ( Jakarta : Bumi Aksara, 2011), h.101.

8 Nashar, Peranan Motivasi dan Kemampuan Awal dalam Kegiatan Pembelajaran (Jakarta: Delia Press, 2004), h.42.

Press), h.75

${ }^{9}$ Sardiman, Interaksi \& Motivasi Belajar Mengajar. (Jakarta: Rajawali 
cita-cita. Adanya keinginan atau cita-cita, maka siswa akan bersungguh-sungguh dalam mengikuti pembelajaran. Siswa akan memperhatikan penjelasan dari guru dan ikut berpartisipasi aktif dalam proses pembelajaran.

Berdasarkan beberapa pendapat tersebut, peneliti menyimpulkan bahwa motivasi belajar merupakan suatu dorongan yang muncul dari dalam diri seseorang untuk melakukan kegiatan belajar guna mencapai prestasi belajar yang optimal.

Ada beberapa Prinsip motivasi dalam belajar yaitu :

a. Motivasi sebagai dasar penggerak yang mendorong aktivitas belajar. Seseorang akan melakukan aktivitas belajar karena ada yang mendorongnya. Motivasilah sebagai dasar penggerak yang mendorong seseorang untuk belajar. Apabila seseorang sudah termotivasi untuk belajar, maka dia akan melakukan aktivitas belajar dalam rentang waktu tertentu. Sehingga motivasi dikatakan sebagai dasar penggerak yang mendorong aktivitas belajar seseorang.

b. Motivasi intrinsik lebih utama dari pada motivasi ekstrinsik dalam belajar. Anak didik yang memiliki motivasi intrinsik akan memiliki semangat belajar yang kuat. Dia belajar bukan karena ingin mendapatkan pujian atau hadiah melainkan karena ingin mendapatkan ilmu sebanyak-banyaknya. Sedangkan anak didik yang memperoleh motivasi ekstrinsik tanpa adanya motivasi intrinsik semangat belajarnya akan mudah lemah. Karena dia kurang percaya diri, bermental pengharapan dan mudah terpengaruh. Dia belajar sematamata hanya untuk memperoleh hadiah.

c. Motivasi berupa pujian lebih baik dari pada hukuman.

Memuji berarti memberikan penghargaan. Dengan pujian akan memberikan semangat kepada anak untuk meningkatkan prestasi belajarnya. Sedangkan hukuman diberikan dengan tujuan untuk memberhentikan perilaku negatif pada anak.

d. Motivasi berhubungan erat dengan kebutuhan dalam belajar.

Kebutuhan yang tidak dapat dihindari dari anak didik adalah kebutuhan untuk memenuhi rasa keingintahuannya, kebutuhan untuk mendapatkan penghargaan, dan perhatian. Oleh karena itu anak didik belajar. Sebagai guru yang berpengalaman cukup bijak memanfaatkan kebutuhan anak didik, untuk memancing semangat 
belajar anak dengan memberikan penghargaan terhadap prestasi anak didik.

e. Motivasi dapat memupuk optimisme dalam belajar.

Anak didik yang memiliki motivasi dalam belajar selalu yakin dapat menyelesaikan tugasnya dengan baik. Dalam dirinya tertanam rasa percaya diri. Meskipun teman yang lain menyontek ketika ulangan, dia tidak akan terpengaruh dan tetap tenang menjawab soalnya.

f. Motivasi melahirkan prestasi dalam belajar.

Anak didik yang menyenangi pelajaran tertentu maka dia akan mempelajarinya dengan tekun dan senang hati. Hasil belajar yang diperoleh pun akan memuaskan. Sehingga tinggi rendahnya motivasi berpengaruh terhadap prestasi belajar anak didik.

Ada tiga elemen penting dalam motivasi yaitu : ${ }^{10}$

a. Bahwa motivasi mengawali terjadinya perubahan energi pada diri setiap individu. Karena motivasi menyangkut perubahan energi manusia, maka penampakannya akan menyangkut kegiatan fisik manusia.

b. Motivasi ditandai dengan munculnya rasa/ "feeling", afeksi seseorang. Motivasi relevan dengan persoalan kejiwaan, afeksi dan emosi yang dapat menentukan tingkah laku manusia.

c. Motivasi akan dirangsang karena adanya tujuan. Motivasi muncul dari dalam diri seseorang, namun kemunculannya karena terangsang oleh adanya unsur lain, dalam hal ini adalah tujuan.

Motivasi memiliki peranan yang penting dalam kegiatan pembelajaran. Tidak ada motivasi berarti tidak ada kegiatan belajar. Supaya peranan motivasi lebih optimal, maka prinsip-prinsip motivasi belajar tidak hanya sekedar diketahui, namun perlu diterapkan dalam proses pembelajaran. Ada beberapa prinsip-prinsip motivasi seperti yang telah uraikan dari beberapa pendapat di atas, yaitu motivasi sebagai dasar penggerak yang mendorong sesorang untuk belajar, motivasi berupa pujian lebih baik daripada hukuman, motivasi dapat memupuk optimisme dalam belajar, motivasi melahirkan prestasi dalam belajar, dan motivasi muncul karena adanya tujuan.

${ }^{10}$ Sardiman, Interaksi \& Motivasi Belajar Mengajar (Jakarta: Rajawali Press, 2009) h.74 


\section{Meningkatkan Motivasi Belajar}

Beberapa siswa tidak terlibat aktif dalam proses pembelajaran. Terkadang sebagian siswa aktif belajar bersama dan sebagian lagi dengan berbagai sikap dan perilaku yang terlepas dari kegiatan belajar dikelas. Keadaan yang bertentangan ini menggambarkan kondisi kelas yang kurang kondusif. Sebagai guru tidak boleh tinggal diam menghadapi kondisi kelas yang seperti ini.

Peranan motivasi baik intrinsik maupun ekstrinsik sangat diperlukan dalam proses pembelajaran. Sebagai guru hendaknya bisa menumbuhkan motivasi anak didik dengan cara yang tepat.

Ada beberapa cara yang dapat dilakukan untuk menumbuhkan motivasi anak didik dalam kegiatan belajar di sekolah yaitu: ${ }^{11}$ (1) memberi angka, dalam hal ini angka sebagai simbol dari nilai kegiatan pembelajaran; (2) hadiah; (3) saingan/kompetisi, persaingan baik individu maupun kelompok dapat memotivasi siswa untuk berprestasi; (4) Ego-involvement, dengan menumbuhkan kesadaran terhadap anak agar merasakan pentingnya tugas dan menerimanya sebagai tantangan adalah salah satu bentuk motivasi yang sangat penting; (5) memberi ulangan, siswa akan menjadi giat belajar jika mengetahui akan ada ulangan; (6) mengetahui hasil, dengan mengetahui hasil belajar apalagi jika terjadi kemajuan akan memotivasi siswa untuk giat belajar; (7) pujian, dengan pujian akan meningkatkan gairah belajar dan membangkitkan harga diri; (8) hukuman, hukuman sebagai reinforcement yang negatif tetapi jika diberikan secara tepat dan bijak bisa menjadi alat motivasi; (9) hasrat untuk belajar, berarti ada unsur kesengajaan dan ada maksud untuk belajar; (10) minat, proses pembelajaran akan berjalan lancar bila disertai dengan minat; (11) tujuan yang diakui, siswa akan termotivasi untuk belajar jika mengetahui tujuan/ pentingnya materi yang akan ia pelajari.

Ada empat upaya yang dapat dilakukan guru sebagai pengajar yang berhubungan dengan cara pemeliharaan dan peningkatan motivasi belajar anak didik yaitu :

a. Guru harus dapat menggairahkan anak didik.

Guru hendaknya menghindari kegiatan yang monoton dan terus menerus dalam proses pembelajaran, sehingga menyebabkan anak didik merasa bosan. Guru harus memelihara minat anak didik

11 Sardiman, Interaksi \& Motivasi Belajar Mengajar (Jakarta: Rajawali Press,2011) hal. 92. 
dengan memberikan kebebasan tertentu dalam situasi belajar dan menggunakan metode pembelajaran yang menarik.

b. Memberi harapan realistis.

Guru perlu memiliki pengetahuan yang cukup mengenai keberhasilan atau kegagalan akademis setiap peserta didik. Sehingga guru dapat memelihara harapan-harapan anak didik yang realistis dan memodifikasi harapan-harapan yang kurang atau tidak realistis.

c. Memberi insentif.

Guru diharapkan dapat memberikan hadiah kepada anak didik yang mengalami keberhasilan dapat berupa pujian, angka yang baik, dan sebagainya.

d. Mengarahkan perilaku anak didik

Mengarahkan anak didik adalah tugas guru. Guru dituntut untuk dapat memberikan respon terhadap anak didik yang pasif, tidak ikut serta dalam pembelajaran, anak didik yang gaduh dengan cara memberikan teguran yang arif dan bijaksana.

Beberapa cara yang dapat dilakukan guru dalam meningkatkan motivasi siswa yaitu :

a. Membangkitkan minat belajar.

Membangkitkan minat belajar dapat dilakukan guru dengan cara mengaitkan pembelajaran dengan minat siswa dan menunjukkan bahwa pengetahuan yang dipelajari sangat bermanfaat bagi siswa. Dengan demikian akan meningkatkan hasrat ingin tahu dan meningkatkan motivasi intrinsik siswa.

b. Mendorong rasa ingin tahu.

Guru yang terampil akan mampu menggunakan cara untuk membangkitkan dan memelihara rasa ingin tahu siswa dalam kegiatan pembelajaran. Meningkatkan rasa ingin tahu siswa dapat dilakukan melalui cerita, dan menggunakan media pembelajaran.

c. Menggunakan variasi metode penyajian yang menarik. Meningkatkan motivasi intrinsik siswa dapat dilakukan melalui penggunaan materi pembelajaran yang menarik serta penggunaan variasi metode penyajian. Metode pembelajaran yang bervariasi akan meningkatkan motivasi siswa dan tidak akan membuat siswa cepat bosan.

d. Membantu siswa dalam merumuskan tujuan belajar.

Prinsip yang mendasar dari motivasi adalah anak akan belajar keras untuk mencapai tujuan apabila tujuan itu dirumuskan oleh dirinya 
sendiri, bukan dirumuskan oleh orang lain. Oleh karena itu, guru hendaknya mendorong dan membantu siswa untuk merumuskan dan mencapai tujuan belajarnya sendiri.

Mengingat demikian pentingnya motivasi bagi siswa dalam kegiatan belajar. Maka guru diharapkan dapat membangkitkan motivasi belajar siswa.

Berdasarkan uraian di atas, peneliti menyimpulkan ada banyak cara yang dapat digunakan guru untuk membangkitkan motivasi belajar siswanya, yaitu dengan menggunakan metode pembelajaran yang bervariasi, menumbuhkan rasa ingin tahu siswa, membangkitkan minat belajar, memberikan hadiah, pujian, dan membantu siswa merumuskan tujuan belajar.

\section{Fungsi Motivasi dalam Belajar}

Setiap kegiatan yang dilakukan pasti didasari oleh adanya motivasi, dan motivasi telah bertalian dengan tujuan. Sehubungan dengan hal tersebut ada tiga fungsi motivasi yaitu $:^{12}$

a. Mendorong manusia untuk berbuat, motivasi dalam hal ini sebagai penggerak dari setiap kegiatan yang akan dikerjakan.

b. Menentukan arah perbuatan, yakni ke arah tujuan yang hendak dicapai.

c. Menyeleksi perbuatan, yakni menentukan perbuatan-perbuatan apa yang harus dikerjakan untuk mencapai tujuan, dengan menyisihkan perbuatan-perbuatan yang tidak bermanfaat bagi tujuan tersebut.

Ada beberapa fungsi motivasi yaitu: ${ }^{13}$

a. Mendorong timbulnya kelakuan atau suatu perbuatan. Tanpa adanya motivasi maka tidak akan timbul suatu perbuatan seperti belajar.

b. Motivasi berfungsi sebagai pengarah. Motivasi mengarahkan perbuatan kepencapaian tujuan yang diinginkan.

c. Motivasi berfungsi sebagai penggerak. Besar kecilnya motivasi akan menentukan cepat atau lambatnya suatu pekerjaan, dalam hal ini kegiatan belajar.

\footnotetext{
12 Sardiman, Interaksi \& Motivasi Belajar Mengajar (Jakarta: Rajawali Press, 2011) h. 82.

${ }^{13}$ Oemar Hamalik,Proses Belajar Mengajar (Jakarta: Bumi Aksara, 2013)

h. 161
} 
Berdasarkan uraian di atas diketahui bahwa motivasi mempunyai fungsi yang penting dalam kegiatan belajar. Motivasi selain sebagai pendorong seseorang untuk melakukan suatu kegiatan juga berfungsi sebagai pengarah yang mengarahkan perbuatan seseorang untuk mencapai tujuannya.

\section{Indikator-Indikator Motivasi Belajar Siswa}

Motivasi yang ada pada diri seseorang memiliki kekuatan yang berbeda-beda. Motivasi yang kuat biasanya bersumber dari diri sendiri (intrinsik). Motivasi yang paling kuat adalah motif yang menjadi sebab untama tingkah laku individu pada saat tertentu. Motif yang lemah hampir tidak mempunyai pengaruh terhadap tingkah laku individu.

Ada beberapa indikator yang dapat digunakan untuk mengetahui kekuatan motivasi belajar yaitu:

a. Tekun menghadapi tugas.

b. Ulet menghadapi kesulitan (tidak mudah putus asa).

c. Menunjukkan minat terhadap macam-macam masalah orang dewasa.

d. Lebih senang bekerja mandiri.

e. Cepat bosan pada tugas-tugas yang rutin.

f. Dapat mempertahankan pendapatnya.

g. Tidak mudah melepaskan hal yang diyakini itu .

h. Senang mencari dan memecahkan masalah soal-soal.

Indikator motivasi belajar adalah sebagai berikut ${ }^{14}$

a. Kuatnya kemauan untuk berbuat.

b. Jumlah waktu yang disediakan untuk belajar.

c. Kerelaan meninggalkan kewajiban atau tugas yang lain.

d. Ketekunan dalam mengerjakan tugas.

Individu yang memiliki motivasi tinggi memiliki karakteristik sebagai berikut: ${ }^{15}$

a. Menyukai situasi atau tugas yang menuntut tanggung jawab pribadi atas hasil-hasilnya dan bukan atas dasar untung-untungan, nasib, atau kebetulan.

14 Martin Handoko, Bimbingan dan Konseling di Sekolah (Yogyakarta: Kanisius, 2010) h. 59.

${ }^{15}$ Djaali, Psikologi Pendidikan (Jakarta : PT Bumi Aksara,2011), h. 109. 
b. Memilih tujuan yang realistis tetapi menantang dari tujuan yang terlalu mudah dicapai atau terlalu besar resikonya.

c. Mencari situasi atau pekerjaan dimana ia memperoleh umpan balik dengan segera dan nyata untuk menentukan baik atau tidaknya hasil pekerjaan.

d. Senang bekerja sendiri dan bersaing untuk mengungguli orang lain.

e. Mampu menangguhkan pemuasan keinginannya demi masa depan yang lebih baik.

f. Tidak tergugah untuk sekedar mendapatkan uang, status, atau keuntungan lainnya, ia akan mencarinya apabila hal-hal tersebut merupakan lambang prestasi, suatu ukuran keberhasilan.

Ciri-ciri motivasi belajar seperti di atas sangat penting dimiliki anak didik dalam proses pembelajaran. Apabila siswa memiliki ketekunan, tidak mudah putus asa, bertanggung jawab, ulet dalam memecahkan masalah, memiliki tujuan yang realistis, mandiri dalam menghadapi hambatan dan adanya kemauan yang kuat untuk belajar, maka pembelajaran akan berjalan dengan baik dan memperoleh hasil yang maksimal. Indikator yang akan dibahas:

a. Tekun dalam belajar.

b. Ulet menghadapi kesulitan.

c. Lebih senang bekerja mandiri.

d. Senang mencari dan memecahkan masalah soal-soal.

e. Kuatnya kemauan dalam belajar.

f. Jumlah waktu yang disediakan untuk belajar

\section{Perhatian Orang Tua}

Perhatian adalah banyak sedikitnya kesadaran yang menyertai sesuatu aktivitas yang dilakukan. ${ }^{16}$ Perhatian sebagai salah satu aktivitas psikis, dapat dimengerti sebagai keaktifan jiwa yang dipertinggi. Jiwa itu pun semata-mata tertuju pada suatu obyek (benda atau hal) ataupun sekumpulan obyek-obyek. ${ }^{17}$ Perhatian adalah pemusatan tenaga/kekuatan jiwa tertuju pada suatu obyek. Perhatian adalah kegiatan yang dilakukan seseorang dalam hubungannya dengan

\footnotetext{
2009), h. 14.

${ }^{17}$ Baharuddin, Psikologi Pendidikan Refleksi Teoritis terhadap Fenomena (Jogjakarta: Ar-Ruzz Media, 2009), h.177.
}

16 Sumadi Suryabrata, Psikologi Pendidikan ( Jakarta: Rajawali Perss, 
pemilihan rangsangan yang datang dari lingkungannya. ${ }^{18}$ Dari uraian tersebut dapat disimpulkan bahwa perhatian adalah pemusatan kesadaran jiwa terhadap suatu objek.

Perhatian merupakan suatu aktivitas yang vital dalam pendidikan. Perhatian dapat diperoleh dari siapa saja, bisa dari guru ataupun orang tua. Dalam penelitian ini perhatian yang dimaksud adalah perhatian yang diberikan oleh orang tua terhadap anaknya. orang tua adalah orang yang dituakan. Namun umumnya di masyarakat pengertian orang tua adalah ayah dan ibu yang melahirkan anak serta berkewajiban untuk mengasuh, merawat, serta mendidik anak tersebut agar menjadi manusia yang berkualitas. Pengetahuan yang pertama diterima oleh anak adalah dari orang tuanya. Jadi orang tua memiliki peranan yang penting atas pendidikan anak-anaknya.

Orang tua adalah pria dan wanita yang terikat dalam perkawinan dan siap sedia untuk memikul tanggung jawab sebagai ayah dan ibu dari anak-anak yang dilahirkannya.

Berdasarkan uraian tersebut dapat disimpulkan bahwa perhatian orang tua adalah proses pemberian bantuan orang tua terhadap anaknya, memberikan bimbingan belajar di rumah, mendorong untuk belajar, memberikan pengarahan pentingnya belajar, memperhatikan kebutuhan-kebutuhan alat yang menunjang pelajaran untuk pencapaian prestasi belajar yang optimal.

\section{Bentuk Perhatian Orang Tua}

Sebagai orang tua yang bertanggung jawab terhadap anaknya maka orang tua memegang fungsi dan peranan penting dalam meningkatkan pendidikan anaknya. Perhatian orang tua terlihat dari usaha orang tua untuk menyediakan fasilitas belajar yang secukupnya. Namun kelengkapan fasilitas belajar anak tidak mutlak menjamin keberhasilan belajar anak apabila tidak diikuti adanya perhatian dari orang tua yang ditunjukkan setiap hari. Gambaran tentang bentuk perhatian orang tua yaitu:

a) Memberikan peringatan.

Peran orang tua dalam hal ini adalah memberikan peringatan terhadap perilaku anaknya. Orang tua memberikan nasihat kepada anak agar tidak melakukan perilaku yang menyimpang.

18 Slameto, Belajar dan Faktor-Faktor yang Mempengaruhi (Jakarta: Rineka Cipta, 2010), hal 105. 
b) Memberikan teguran.

Orang tua menegur tindakan anak yang salah dan memberikan penjelasan kepada anak mengapa hal tersebut salah serta menunjukkan hal yang benar. Orang tua memiliki kewajiban untuk mengontrol perilaku anak dan membimbing anak apabila anak melakukan kesalahan.

c) Memperhatikan penyediaan sarana studi.

Sarana prasarana studi merupakan komponen yang penting dalam proses belajar anak. Apabila sarana prasarana tidak memadahi maka proses belajar anak akan terhambat. Orang tua memiliki kewajiban untuk menyediakan sarana dan prasarana yang dibutuhkan anak untuk belajar. Sehingga proses belajar anak berjalan dengan lancar. yaitu:

Perhatian orang tua dapat ditunjukkan dalam berbagai bentuk

a) Penyediaan dan pengaturan waktu belajar anak.

Waktu adalah sesuatu yang dibutuhkan oleh anak yang sedang belajar. Orang tua harus menyediakan waktu untuk mendampingi belajar anak dan memberikan waktu sebaik-baiknya jangan sampai waktu yang digunakan untuk belajar digunakan untuk yang lain, atau terganggu aktivitas lain, maka apabila ini terjadi akan mengganggu proses belajar anak dan pada akhirnya akan berdampak pada prestasi belajar anak. Orang tua dapat berperan membantu mengatur waktu belajar anak dengan cara memperhitungkan waktu setiap hari, menentukan waktu yang tersedia setiap hari, merencanakan materi pelajaran yang akan dipelajari, dan menentukan waktu yang dapat dipergunakan untuk belajar dengan hasil terbaik.

b) Bantuan mengatasi masalah.

Yang dimaksud dengan bantuan mengatasi masalah adalah membantu mengatasi masalah yang dihadapi anak ketika belajar baik kesulitan-kesulitan anak dalam membaca, menulis, mengerjakan pekerjaan rumah, menyatakan pendapat baik tulis maupun lisan.

c) Pengawasan belajar anak.

Anak memerlukan pengawasan dari orang tua agar sikap dewasa dan tanggung jawab belajar tumbuh pada diri anak. Orang tua hendaknya meluangkan waktu untuk mengawasi dan mendampingi 
anak dalam belajar. Anak yang tidak mendapatkan pengawasan dari orang tua akan banyak mengalami kesulitan belajar.

d) Penyediaan Fasilitas Belajar.

Fasilitas dalam dunia pendidikan berarti segala sesuatu yang bersifat fisik maupun material, yang dapat memudahkan terselenggaranya dalam proses belajar mengajar, misalnya dengan tersedianya tempat perlengkapan belajar di kelas, alat-alat peraga pengajaran, buku pelajaran, perpustakaan, berbagai perlengkapan praktikum laboraturium dan segala sesuatu yang menunjang terlaksananya proses belajar mengajar.

Adapun yang dimaksud dengan fasilitas belajar adalah semua kebutuhan yang diperlukan oleh peserta didik dalam rangka untuk memudahkan, melancarkan dan menunjang dalam kegiatan belajar disekolah. Supaya lebih efektif dan efisien yang nantinya peserta didik dapat belajar dengan maksimal dan hasil belajar yang memusakan.

Fasilitas atau alat belajar akan sangat penting dan dominan bagi anak yang sedang menekuni belajarnya. Keadaan peralatan seperti pensil, tinta, penggaris, buku tulis, buku pelajaran, jangka dan lain-lain akan membantu kelancaran dalam belajar. Kurangnya alat-alat tersebut akan menghambat proses belajar anak.

Berdasarkan penjelasan di atas, dapat disimpulkan bahwa perhatian orang tua dapat diberikan dalam bentuk penyediaan dan mengatur waktu belajar anak, memberikan peringatan, memberikan teguran, membantu anak menyelesaikan masalah belajar, pengawasan belajar anak serta penyediaan fasilitas belajar.

\section{Faktor-faktor yang mempengaruhi perhatian orang tua}

Perhatian tidak selamanya dapat diarahkan dengan baik. Hal ini dikarenakan bahwa perhatian dipengaruhi oleh beberapa faktor :

a. Ditinjau dari hal-hal yang bersifat objektif, yaitu rangsangan yang kuat mendapatkan perhatian, kualitas rangsangan mempengaruhi perhatian, objek yang besar menarik perhatian, begitu pula rangsangan dapat menarik perhatian.

b. Ditinjau dari hal-hal yang secara subjektif, yaitu hal-hal yang bersangkut paut dengan pribadi subjek, misalnya : beberapa 
rangsangan yang sesuai dengan bakatnya lebih menarik perhatian daripada hal yang lain ${ }^{19}$.

Faktor-faktor yang mempengaruhi perhatian menjadi dua yaitu faktor obyektif dan subyektif. Faktor obyektif yang dapat menarik perhatian seseorang adalah : ${ }^{20}$

a) Adanya rangsangan yang kuat.

b) Kualitas rangsangan.

c) Adanya objek yang besar/luas.

d) Adanya stimulus yang baru. adalah :

Sedangkan faktor subyektif yang dapat menarik perhatian

a. Adanya stimulus yang membawanya mengandung daya tarik.

b. Adanya arti atau maksud pada sesuatu dapat menimbulkan daya tarik.

c. Ketidakpastian menimbulkan daya tarik.

d. Emosi yang tetap (terbiasa) dapat menentukan daya tarik.

Berdasarkan pendapat di atas dapat dijabarkan bahwa faktor yang mempengaruhi perhatian orang tua antara lain :

1. Faktor Objektif yang meliputi :

a) Rangsangan yang kuat.

Orang tua memiliki perasaan yang sangat peka terhadap anaknya. Apabila anak dirasa sedang kelihatan lain daripada keadaan biasanya, maka orang tua dengan mendapat rangsangan yang sangat kuat untuk segera memberikan perhatian kepada anak dengan tujuan dapat memberikan sesuatu yang sedang dibutuhkan. Misalnya anak nampak murung, maka orang tua segera memberikan perhatian agar anak tersebut dapat membebaskan dari kemurungan itu.

b) Kualitas Rangsangan.

Orang tua dalam memberikan perhatian kepada anak tidak bersifat terus menerus, namun dapat memilih sekiranya anak sedang sangat membutuhkan perhatian. Hal ini dapat terjadi pada saat anak sedang menghadapi ulangan misalnya. Maka orang tua memandang bahwa situasi pada saat itu sangat membutuhkan perhatian agar anak

${ }^{19}$ Mawarsih, Siska Eko, and Nurhasan Hamidi. "Pengaruh perhatian orang tua dan motivasi belajar terhadap prestasi belajar siswa sma negeri jumapolo." JupeJurnal Pendidikan Ekonomi 1, no. 3 (2013).

${ }^{20}$ Baharuddin, Psikologi Pendidikan Refleksi Teoritis terhadap Fenomena (Jogjakarta: Ar-Ruzz Media, 2009), h. 181. 
dapat belajar dengan sungguh-sungguh. Situasi sedang menghadapi ulangan adalah salah satu contoh kualitas rangsangan yang membuat orang tua memberikan perhatian.

c) Objek yang besar atau perangsang luar biasa.

Setiap orang memiliki emosi atau dorongan yang tersimpan dalam hati, hal ini dapat muncul jika ada objek yang dapat menarik perhatian secara tiba-tiba tanpa diduga sebelumnya, sehingga perhatian muncul dengan dorongan yang sangat kuat atau luar biasa. Misalnya orang tua mempunyai keinginan di dalam hati agar anaknya dapat meraih prestasi yang tinggi, jika benar-benar anak dapat mewujudkan keinginan orang tua tersebut, maka anak akan mendapatkan perhatian yang lebih besar.

d) Rangsangan yang baru.

Anak diharapkan dapat berkembang sesuai dengan potensi yang dimiliki. Jika dalam perkembangannya mempunyai kreatifitas menuju hal-hal yang positif, maka orang tua akan memberikan perhatian pula untuk mendukung kegiatan tersebut.

2. Faktor Subjektif yang meliputi :

a) Adanya stimulus yang mengandung daya tarik.

Anak akan mudah ingat jika ada sesuatu yang menarik perhatiannya. Orang tua dapat memanfaatkan hal ini untuk membantu proses belajar anak di rumah. Orang tua bisa memberikan buku bergambar, CD interaktif atau game pembelajaran yang menarik perhatian anak dan menyenangkan.

b) Adanya arti maksud yang menimbulkan daya tarik

Menimbulkan daya tarik anak bisa dilakukan dengan penggunaan kata-kata yang menarik. Orang tua dalam memberikan bimbingan belajar dan nasihat kepada anaknya dapat dilakukan dengan menggunakan cerita ataupun dongeng, sehingga anak merasa senang dan mudah menerima informasi yang disampaikan oleh orang tua.

c) Ketidakpastian menimbulkan daya tarik.

Menarik perhatian anak juga dapat dilakukan dengan membuat anak merasa penasaran. Terkadang orang tua tidak harus selalu menjawab apa yang ditanyakan anak, dan memenuhi semua yang diinginkan anak. Membuat anak menunggu dalam ketidakpastian dan akhirnya anak akan mencari jawaban sendiri. Hal ini akan menjadikan anak mandiri, timbul rasa penasaran dan tertantang. 
d) Emosi yang tetap dapat menimbulkan daya tarik

Keadaan perasaaan orang tua sangat berpengaruh terhadap minat belajar anak. Hal ini dapat terjadi jika orang tua yang bekerja perasaan gembira akan membuat suasana rumah yang menyenangkan. Sebaliknya, orang tua yang bekerja dengan perasaan marah membuat suasana rumah menjadi kurang menyenangkan sehingga minat untuk belajarpun bagi anak berkuran/menurun. Orang tua hendaknya selalu menjaga emosinya terutama di depan anak-anak ${ }^{21}$.

Berdasarkan penjelasan mengenai faktor-faktor yang mempengaruhi perhatian orang tua, maka dapat disimpulkan bahwa perhatian orang tua dapat dipengaruhi dua faktor yaitu faktor objektif dan subjektif. Faktor objektif cenderung timbul karena dorongan dari dalam diri individu, sedangkan faktor subjektif cenderung timbul dari luar diri individu. Kedua faktor tersebut bagi orang tua dapat muncul dengan sendiri ataupun bersama-sama tergantung pada objek yang sedang dihadapi. Perhatian orang tua yang diberikan kepada anaknya sangat berpengaruh terhadap perkembangan anak khususnya pada minat belajar dan kegiatan-kegiatan lain yang dapat memberikan kontribusi yang positif terhadap anak.

\section{Kesiapan Belajar}

Kesiapan (readiness) adalah kapasitas/kemampuan potensial baik bersifat fisik maupun mental untuk melakukan sesuatu. Kesiapan adalah keseluruhan kondisi seseorang yang membuatnya siap untuk memberi respon/jawaban di dalam cara tertentu terhadap suatu situasi. Kesiapan memberikan sumbangan yang besar pada siswa dalam menerima pengetahuan, karena secara tidak langsung kondisi tersebut telah menyiapkan otak untuk memberi respon ${ }^{22}$.

Kesiapan belajar sangat penting dijadikan landasan dalam proses pembelajaran. Tanpa adanya kesiapan proses belajar tidak akan maksimal. Apabila siswa siap melakukan proses belajar, maka akan diperoleh hasil belajar yang baik. Sebaliknya jika siswa tidak siap untuk belajar, tidak akan diperoleh hasil yang baik. Oleh karena itu,

${ }^{21}$ Dwija, I. Wayan. "Hubungan antara konsep diri, motivasi berprestasi dan perhatian orang tua dengan hasil belajar Sosiologi pada siswa kelas II Sekolah Menengah Atas unggulan di Kota Amlapura." Jurnal Pendidikan dan Pengajaran 41, no. 1 (2008).

22 Mulyani, Dessy. "Hubungan kesiapan belajar siswa dengan prestasi belajar." Konselor 2, no. 1 (2013). 
pembelajaran sebaiknya dilakukan jika individu memiliki kesiapan untuk belajar ${ }^{23}$.

Kesiapan belajar adalah kondisi-kondisi yang mendahului kegiatan belajar itu sendiri. Kesiapan belajar merupakan kemampuan seseorang untuk mendapatkan keuntungan dari pengalaman belajar yang ia temukan. Dari uraian di atas dapat disimpulkan yang dimaksud dengan kesiapan belajar adalah kemampuan seseorang baik fisik maupun mental untuk melakukan kegiatan belajar.

\section{Faktor-faktor yang mempengaruhi kesiapan belajar.}

Ada beberapa faktor yang dapat mempengaruhi kesiapan belajar siswa. Faktor kesiapan belajar meliputi : a) Kondisi fisik yang tidak kondusif. Misalnya sakit, pasti akan mempengaruhi faktor-faktor lain yang dibutuhkan untuk belajar. b) Kondisi psikologis yang kurang baik. Misalnya gelisah, tertekan, dsb. merupakan kondisi awal yang tidak menguntungkan bagi kelancaran belajar. Menjelaskan kondisi kesiapan mencakup 3 aspek, yaitu : a) Kondisi fisik, mental dan emosional, b) Kebutuhan-kebutuhan, motif dan tujuan, c) Ketrampilan, pengetahuan dan pengertian yang lain yang telah dipelajari.

Faktor yang membentuk kesiapan belajar meliputi ${ }^{24}$ :

a) Perlengkapan dan pertumbuhan fisiologi; ini menyangkut pertumbuhan terhadap kelengkapan pribadi seperti tubuh pada umumnya, alat-alat indera, dan kapasitas intelektual.

b) Motivasi, yang menyangkut kebutuhan, minat serta tujuan-tujuan individu untuk mempertahankan serta mengembangkan diri.

Faktor-faktor yang mempengaruhi kesiapan belajar meliputi:

a) Kesiapan fisik ${ }^{25}$

23 Wahyuni, Dwi. "Pengaruh Kesiapan Belajar, Motivasi Belajar dan Pengulangan Materi Pelajaran Terhadap Hasil Belajar Mata Pelajaran Ekonomi pada Siswa Kelas II MA Al Asror Gunung Pati Tahun Pelajaran 2004/2005." PhD diss., Universitas Negeri Semarang, 2005.

24 Nidhom, Ahmad Mursyidun, Ahmad Sonhadji KH, and Dwi Agus Sudjimat. "Hubungan Kesiapan Belajar, Lama Pembelajaran, Kesesuaian Tempat dan Partisipasi DU/DI dengan Hasil Prakerin Peserta Didik Kompetensi Keahlian TKJ di SMK Kota Batu." Innovation of Vocational Technology Education 11, no. 1 (2015). Lihat juga Mulyani, Dessy. "Hubungan kesiapan belajar siswa dengan prestasi belajar." Konselor 2, no. 1 (2013). 
Kesiapan fisik berkaitan erat dengan kesehatan yang akan berpengaruh pada hasil belajar dan penyesuaian sosial individu. Individu yang kurang sehat mungkin kurangnya vitamin, badanya kurang energi untuk belajar. Hal ini dapat mempengaruhi pada kelancaran proses belajar. Begitupun sebaliknya jika badan tidak sakit (jauh dari gangguan lesu mengantuk, dan sebagainya). Hal ini akan memudahkan untuk belajar karena tidak ada gangguan dari kondisi fisiknya.

b) Kesiapan psikis ${ }^{26}$

Kesiapan psikis berkaitan dengan kecerdasan, daya ingat tinggi, kebutuhan yang terpuaskan, ada hasrat atau motivasi untuk belajar, dapat berkonsentrasi, dan ada perhatian.

c) Kesiapan Materiil ${ }^{27}$

Individu dalam mempelajari materi tentunya harus mempunyai bahan yang dapat dipelajari atau dikerjakan, misalnya buku bacaan, buku paket dari sekolah maupun diktat lain yang relevan digunakan sebagai bahan acuan belajar, mempunyai buku catatan dll. Dengan di dukung berbagai sumber bacaan maka akan memberikan pengetahuan dan akan membantu siswa dalam merespon atas pertanyaanpertanyaan dari guru terkait dengan pelajaran.

Berdasarkan penjelasan di atas dapat disimpulkan bahwa terdapat beberapa faktor yang mempengaruhi kesiapan belajar siswa, yaitu kesiapan fisik, psikis, dan materiil. Kesiapan fisik berkaitan dengan kondisi tubuh siswa. kesiapan psikis berkaitan dengan kecerdasan, sedangkan kesiapan materiil meliputi kesiapan alat-alat yang dibutuhkan dalam proses pembelajaran, yaitu: buku tulis, buku paket, pensil, dan lain sebagainya.

${ }^{25}$ Halimah, Nur, and Fajar Kawuryan. "Kesiapan memasuki sekolah dasar Pada anak yang mengikuti pendidikan TK dengan yang tidak mengikuti pendidikan TK di kabupaten kudus." Jurnal Psikologi UMK: PITUTUR 1, no. 1 (2010): 1-8.

26 Widyaningtyas, Anisa, and Yohanes Radiyono. "Peran lingkungan belajar dan kesiapan belajar terhadap prestasi belajar fisika siswa kelas X Sekolah Menengah Atas Negeri 1 Pati." Jurnal Pendidikan Fisika 1, no. 1 (2013): 136-143.

27 Rahmattika, Nur Indah. "Pengaruh Kesiapan dan Disiplin Belajar terhadap Prestasi Belajar Mata Pelajaran Ekonomi Akuntansi Siswa Kelas XI IS SMA Negeri 5 Tegal Tahun Pelajaran 2009/2010." PhD diss., Universitas Negeri Semarang, 2011. 


\section{Hubungan Motivasi dan Perhatian Orang Tua dengan Kesiapan Belajar}

Kesiapan belajar merupakan kemampuan seseorang baik fisik maupun mental untuk melakukan kegiatan belajar. Kesiapan belajar dipengaruhi oleh beberapa faktor seperti yang diungkapkan oleh beberapa ahli. Kesiapan belajar dibentuk oleh dua faktor, yaitu (1) perlengkapan dan pertumbuhan fisiologi, (2) motivasi. Motivasi belajar merupakan dorongan yang ada dalam diri siswa untuk melakukan kegiatan belajar demi mencapai prestasi yang optimal. Semakin tinggi motivasi belajar siswa maka semakin tinggi pula kesiapan belajar siswa. Siswa yang memiliki motivasi belajar tinggi akan menyiapkan segala sesuatu yang dibutuhkan dalam proses pembelajaran $^{28}$.

Kesiapan belajar siswa dipengaruhi oleh perhatian orang tua ${ }^{29}$. Perhatian orang tua merupakan suatu proses pemberian bantuan orang tua terhadap anaknya, mendorong untuk belajar, memberikan pengarahan pentingnya belajar, memperhatikan kebutuhan-kebutuhan alat yang menunjang pelajaran untuk pencapaian prestasi belajar yang optimal. Pada usia sekolah dasar anak belum dapat menyiapkan sendiri segala yang dibutuhkan untuk kegiatan belajarnya. Di sinilah peran orang tua dibutuhkan untuk membantu kesiapan belajar anak. Semakin tinggi perhatian orang tua terhadap anaknya maka semakin tinggi pula kesiapan belajar anak.

Siswa yang memiliki motivasi dan memperoleh perhatian dari orang tua maka akan mempunyai kesiapan belajar yang tinggi. Siswa yang memiliki kesiapan belajar tinggi akan menyiapkan segala yang dibutuhkan dalam kegiatan belajar dan selalu siap untuk melakukan proses pembelajaran. Siswa akan mengikuti kegiatan belajar dengan baik dan mendapatkan hasil belajar yang memuaskan.

\section{Kesimpulan}

Peserta didik pada tingkat sekolah dasar memerlukan penanganan pada dua ranah, yakni keluarga dan lingkungan. Lembaga

\footnotetext{
${ }^{28}$ Fatchurrohman, Rudy. "Pengaruh motivasi berprestasi terhadap kesiapan belajar, pelaksanaan prakerin dan pencapaian kompetensi mata pelajaran produktif." Innovation of Vocational Technology Education 7, no. 2 (2011).

29 Sulistyaningsih, Wiwik. "Kesiapan bersekolah ditinjau dari jenis pendidikan pra sekolah anak dan tingkat pendidikan orangtua." (2005).
} 
pendidikan yang pertama kali dikenal oleh seorang anak adalah keluarga, melalui kedua orang tuanya. Kesadaran orang tua terhadap fase pendidikan anak di lingkungan keluarga harus betul-betul nampak dalam kegiatan-kegiatan edukatif. Tuntas pada lingkungan keluarga akan menjadi momentum yang indah ketika sang anak melangkah ke lingkungan persekolahan. Waktu yang dihabiskan oleh siswa di sekolah tidak sepadan di rumah, namun desain sekolah sejatinya lebih sistematis dalam pelaksanaan pendidikan dan pembelajaran. Iklim sekolah diciptakan untuk menopang tumbuh kembang siswa, terutama kesiapan belajar. Demikian pula peran guru dalam memanfaatkan berbagai sumber daya sekolah secara kreatif untuk memantik semangat siswa mengikuti kegiatan pembelajaran.

\section{Daftar Pustaka}

Baharuddin, Psikologi Pendidikan Refleksi Teoritis terhadap Fenomena (Jogjakarta: Ar-Ruzz Media, 2009)

Bangun, Darwin. "Hubungan persepsi siswa tentang perhatian orang tua, kelengkapan fasilitas belajar, dan penggunaan waktu belajar di rumah dengan prestasi belajar ekonomi." Jurnal ekonomi dan pendidikan 5, no. 1 (2008).

Djaali, Psikologi Pendidikan ( Jakarta : Bumi Aksara, 2011)

Djamarah, Syaiful Bahri, Rahasia Sukses Belajar (Jakarta: Rineka Cipta, 2008)

Dwija, I. Wayan. "Hubungan antara konsep diri, motivasi berprestasi dan perhatian orang tua dengan hasil belajar Sosiologi pada siswa kelas II Sekolah Menengah Atas unggulan di Kota Amlapura." Jurnal Pendidikan dan Pengajaran 41, no. 1 (2008).

Fatchurrohman, Rudy. "Pengaruh motivasi berprestasi terhadap kesiapan belajar, pelaksanaan prakerin dan pencapaian kompetensi mata pelajaran produktif." Innovation of Vocational Technology Education 7, no. 2 (2011).

Halimah, Nur, and Fajar Kawuryan. "Kesiapan memasuki sekolah dasar Pada anak yang mengikuti pendidikan TK dengan yang tidak mengikuti pendidikan TK di kabupaten kudus." Jurnal Psikologi UMK: PITUTUR 1, no. 1 (2010): 1-8. 
Hamalik, Oemar, Proses Belajar Mengajar (Jakarta: Bumi Aksara, 2013)

Handoko, Martin, Bimbingan dan Konseling di Sekolah (Yogyakarta: Kanisius, 2010)

Kurniawan, Didik, and Dhoriva Urwatul Wustqa. "Pengaruh perhatian orangtua, motivasi belajar, dan lingkungan sosial terhadap prestasi belajar matematika siswa SMP." Jurnal riset pendidikan matematika 1, no. 2 (2014): 176-187.

Mawarsih, Siska Eko, and Nurhasan Hamidi. "Pengaruh perhatian orang tua dan motivasi belajar terhadap prestasi belajar siswa sma negeri jumapolo." Jupe-Jurnal Pendidikan Ekonomi 1, no. 3 (2013).

Mulyani, Dessy. "Hubungan kesiapan belajar siswa dengan prestasi belajar." Konselor 2, no. 1 (2013).

Nashar, Peranan Motivasi dan Kemampuan Awal dalam Kegiatan Pembelajaran (Jakarta: Delia Press, 2004),

Nidhom, Ahmad Mursyidun, Ahmad Sonhadji KH, and Dwi Agus Sudjimat. "Hubungan Kesiapan Belajar, Lama Pembelajaran, Kesesuaian Tempat dan Partisipasi DU/DI dengan Hasil Prakerin Peserta Didik Kompetensi Keahlian TKJ di SMK Kota Batu." Innovation of Vocational Technology Education 11 , no. 1 (2015).

Sardiman, Interaksi \& Motivasi Belajar Mengajar (Jakarta: Rajawali Press 2017)

Slameto, Belajar dan Faktor-Faktor yang Mempengaruhi (Jakarta: Rineka Cipta, 2010)

Rahmattika, Nur Indah. "Pengaruh Kesiapan dan Disiplin Belajar terhadap Prestasi Belajar Mata Pelajaran Ekonomi Akuntansi Siswa Kelas XI IS SMA Negeri 5 Tegal Tahun Pelajaran 2009/2010." PhD diss., Universitas Negeri Semarang, 2011.

Sugihartono, Psikologi Pendidikan (Yogyakarta: UNY Press 2007)

Sulistyaningsih, Wiwik. "Kesiapan bersekolah ditinjau dari jenis pendidikan pra sekolah anak dan tingkat pendidikan orangtua." (2005).

Suryabrata, Sumadi, Psikologi Pendidikan ( Jakarta: Rajawali Perss, 2009)

Wahyuni, Dwi. "Pengaruh Kesiapan Belajar, Motivasi Belajar dan Pengulangan Materi Pelajaran Terhadap Hasil Belajar Mata Pelajaran Ekonomi pada Siswa Kelas II MA Al Asror 
Gunung Pati Tahun Pelajaran 2004/2005." PhD diss., Universitas Negeri Semarang, 2005.

Widyaningtyas, Anisa, and Yohanes Radiyono. "Peran lingkungan belajar dan kesiapan belajar terhadap prestasi belajar fisika siswa kelas X Sekolah Menengah Atas Negeri 1 Pati." Jurnal Pendidikan Fisika 1, no. 1 (2013): 136-143. 